\title{
$\mathrm{CD} 30$ 활성화에 의한 호산구 자멸사에서 caspase-9의 매개작용
}

\author{
가톨릭대학교 의과대학 소아과학교실 ${ }^{1}$, 서울대학교 의과대학 소아과학교실 ${ }^{2}$ \\ 이혜진 ${ }^{1} \cdot$ 이근영 $^{1} \cdot$ 김유진 $^{1} \cdot$ 장필상 $^{1} \cdot$ 윤종서 $^{1} \cdot$ 김현희 $^{1} \cdot$ 고영률 $^{2} \cdot$ 김진택 $^{1} \cdot$ 이준성 $^{1}$
}

\begin{abstract}
$=\mathbf{A b s t r a c t}=$
\section{CD30 Activation Induced Eosinophil Apoptosis is Mediated by Caspase- 9}

\author{
Hye Jin Lee, $\mathrm{MD}^{1}$, Keun Young Lee, $\mathrm{MD}^{1}$, Yoo Jin Kim, MD ${ }^{1}$, Pil Sang Jang, $\mathrm{MD}^{1}$, \\ Jong Seo Yoon, $\mathrm{MD}^{1}$, Hyun Hee Kim, $\mathrm{MD}^{1}$, Young Yull Koh, $\mathrm{MD}^{2}$, \\ Jin Tack Kim, $\mathrm{MD}^{1}$, Joon Sung Lee, $\mathrm{MD}^{1}$
}

${ }^{1}$ Department of Pediatrics, The Catholic University of Korea School of Medicine, Seoul,

${ }^{2}$ Department of Pediatrics, Seoul National University College of Medicine, Seoul, Korea
\end{abstract}

Purpose : Although CD30 is known to be expressed more on eosinophils undergoing apoptosis, it is still not known how CD30 activation leads to eosinophil apoptosis. In this study, we evaluated whether ligation of CD30 incites apoptosis and investigated whether the mechanisms of CD30 induced eosinophil apoptosis are dependent on caspase activation.

Methods : We drew $90 \mathrm{~mL}$ of peripheral blood from healthy donors and then purified eosinophils using a MACS system. Expression of CD30 on eosinophils was measured, and eosinophils were cultured in wells pretreated with anti-CD30 mAb, isotype control immunoglobulin G1, interleukin (IL)-5, and dexamethasone in Roswell Park Memorial Institute 1640 media supplemented with 10\% fetal bovine serum. Their rates of apoptosis were then compared using flow cytometry. To evaluate whether caspase-9 is involved in CD30-induced eosinophil apoptosis, the apoptotic rate was evaluated after the addition of caspase- 9 inhibitor. The expression of procaspase- 9 was also measured using Western blot.

Results : Expression of CD30 molecules on eosinophils increased steadily as the culture time lapse. The apoptotic rates of eosinophils cultured in the presence of anti-CD30 mAb were significantly increased to $29.1 \pm 6.1 \%$ and $47.3 \pm 4.7 \%$ compared to $17.1 \pm 6.7 \%$ and $29.4 \pm 9.2 \%$ of the control at 4 and 24 hours, respectively (both $P<0.05$ ). The apoptotic rates of eosinophils treated with anti-CD30 mAb were even faster than those of eosinophils treated with dexamethasone, and the $\mathrm{mAb}$ also suppressed the IL-5-induced enhancing effect of eosinophil survival. Caspase-9 inhibitor suppressed mAb induced eosinophil apoptosis from $54.8 \pm 6.9 \%$ and $71.5 \pm 11.6 \%$ to $24.5 \pm$ $6.0 \%$ and $47.8 \pm 11.4 \%$ at 18 and 36 hours, respectively (both $P<0.001$ ). We also demonstrated that the expression of procaspase -9 with mAb was diminished compared to that of the control and of IL-5.

Conclusion : This study showed CD30 activation enhances eosinophil apoptosis, and the effect is mediated by caspase-9 activation. [Pediatr Allergy Respir Dis(Korea) 2011;21:115-122]

본 연구는 2008년도 대한소아알레르기호흡기학회 Outstanding Fellow Award를 위한 건일제약 연구지원금에 의해 일부 이루어진 연구임. 접수 : 2011년 5월 17일, 수정 : 2011년 6월 2일, 승인 : 2011년 6월 6일

책임저자 : 김진택, 경기도 의정부시 금오동 65-1 가톨릭대학교 의정부성모병원 소아청소년과

Tel : 031)820-3107 Fax : 031)821-3108 E-mail : jintackk@catholic.ac.kr 
Key Words : CD30, Eosinophil apoptosis, Caspase-9

\section{서 론}

호산구는 알레르기염증을 일으키는 중요한 작동세포 (effector cell)이며 과립단백 (granular proteins), 사이토 카인(cytokine), 지질매개체 (lipid mediators) 등 알레르기 염증반응의 시작과 유지에 관여하는 다양한 세포독성물질 들(cytotoxic substances)을 가지고 있다. ${ }^{1)}$ 호산구의 수 명 연장과 사멸 감소는 알레르기 염증반응을 지속시키는 것 으로 알려져 있으며 ${ }^{2}$ 호산구 생존 및 제거와 관련된 요소들 에 많은 관심이 집중되고 있다. 호산구 생존은 interleukin (IL) -3, IL-5, granulocyte-macrophage colony-stimulating factor (GM-CSF)에 의해 주로 야기되며 특히 IL-5는 호산구 세포 내 생존친화성 신호전달체계를 활성시킨다. ${ }^{3)}$

세포사멸은 괴사와 자멸사(apoptosis) 가 있으며 전자는 급성 세포손상으로 인해 세포사멸이 일어나므로 염증반응 을 일으키지만 자멸사는 염증매개물질을 분비하지 않고 세 포가 수축하여 대식세포에 의해 염증의 동반 없이 제거되며 4,5) caspase가 인체세포의 자멸사에 중요한 역할을 하는 것 으로 알려졌다 ${ }^{6)}$. 호산구 자멸사는 조직손상 없이 알레르기 염증반응을 종결시키는 중요한 과정이며 $\mathrm{CD} 95,{ }^{7)} \mathrm{CD} 69,{ }^{8)}$ $\mathrm{CD} 45^{9)}$ 등의 호산구의 세포막 표면 수용체에 의해 자멸사 가 유도되는 것으로 알려져 있다. CD30은 tumor necrosis factor receptor (TNFR) family에 속하며 호지킨림프 종의 Hodgkin and Reed Sternberg 세포에서 처음 관찰되 었다. ${ }^{10)}$

CD30은 주로 activated T cells, 자연세포독성세포 $(\mathrm{NK}$ cells), 인체면역결핍바이러스(human immunodeficiency virus)나 엡스타인-바 바이러스(Epstein-Barr virus)에 감 염된 림프구 표면에서 발현되며 ${ }^{11)} \mathrm{CD} 30$ 가 활성화 될 때 세 포 종류에 따라 세포가 증식되거나 한편으로 자멸사 하기도 하는 다양한 생물학적 효과를 나타낸다. ${ }^{12-16)}$ 과거에 CD30 은 호산구에 존재하지 않는 것으로 알려졌으나 ${ }^{17,18)}$ 자멸사 가 진행중인 호산구에서는 발현이 증가된다는 보고들도 있 다. ${ }^{19,20)}$ 그러나 실제 $\mathrm{CD} 30$ 활성화가 어떻게 호산구 자멸사 를 일으키는지는 아직 명확하지 않다. 본 연구에서는 호산구 의 CD30 발현여부를 확인하고 CD30 활성화에 의해 호산 구 자멸사가 유도되는지 여부와 그 자멸사 기전에 caspase 가 관여하는지를 밝히고자 하였다.

\section{대상 및 방법}

\section{1. 대 상}

가톨릭대학교 의정부성모병원 임상시험심사위원회의 공 인 동의서 작성에 동의하고 알레르기질환의 기왕력이 없는 건강한 24 명 성인들의 말초혈액 $90 \mathrm{~mL}$ 를 채취하였다.

\section{2. 방 법}

\section{1) 호산구 분리}

혈액을 Percoll (GE health care, Uppsala, Sweden) 용액을 이용하여 밀도차에 의해 원심분리한 후 과립구들을 anti-CD16 Ab coated immunomagnetic beads (Miltenyi Biotec, Bergisch Gladbach, Germany) 와 1시간 배양 하여 MACS magnetic system을 통해 호산구를 선택적으 로 분리하였다 ${ }^{21)}$. 분리된 호산구 수와 생존능 (viability)의 측정은 Randolph 염색하여 hemocytometer와 trypan blue dye exclusion method로 각각 평가하였으며 순도 (purity) 와 생존능은 모두 98\% 이상이었다. 호산구는 10\% fetal bovine serum (FBS)이 첨가된 Roswell Park Me-

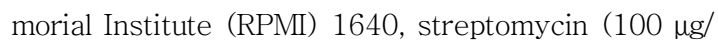
$\mathrm{mL}$ )에 $1 \times 10^{6} \mathrm{cells} / \mathrm{mL}$ 의 농도로 재현탁하고 모든 실험은 각각 4 회 시행하였다.

\section{2) 호산구의 CD30 발현}

호산구 표면에 발현되는 CD30 표현정도는 flow cytometry를 이용하여 측정하였다. ${ }^{22)}$ 분리한 호산구를 $0.1 \%$ bovine serum albumin (BSA; Sigma-Aldrich Co., St. Louis, $\mathrm{MO}$, USA) 와 $4 \mathrm{mg} / \mathrm{mL}$ human immunoglobulin $\mathrm{G}$ (IgG; Sigma-Aldrich Co.)가 함유된 Dulbecco's phosphate-buffered saline (PBS)에서 포화농도의 항 $\mathrm{CD} 30$ 항 체 또는 동형의 대조항체와 각각 $4^{\circ} \mathrm{C}$ 에서 30 분간 표지하였 다. 세포를 세척한 후 적정농도의 FITC-conjugated $\mathrm{F}\left(\mathrm{ab}^{\prime}\right)_{2}$ goat anti-mouse IgG (BD Biosciences, San Jose, CA, USA) 와 함께 PBS-BSA에서 $4^{\circ} \mathrm{C}, 30$ 분간 다시 배양하였다. $1 \%$ paraformaldehyde 로 고정 후 FACScan 유세포분석기(flow cytometry, BD, Franklin Lakes, NJ, USA)을 이용하여 형광분석하였다. 형광강도는 logarithmic amplification을 이용하여 각 검체의 20,000 개 세포를 대상으로 결정하였고 Becton Dickenson lysis II soft- 
ware를 통하여 linear equivalent로 전환시켰다.

\section{3) 호산구 배양}

$\mathrm{CD} 30$ 활성화가 호산구 자멸사에 미치는 영향은 CD30 단클론항체인 Ber-H8 (BD Biosciences) 처리군과 대조군 인 동형의 IgG1 (Santa Cruz Biotechnology Inc., Santa Cruz, CA, USA) 및 순수배양액의 자멸사율을 각각 비교 평가하였다.

각 항체들을 PBS용액에 $20 \mu \mathrm{g} / \mathrm{mL}$ 로 부유시킨 후 flat bottom 24 well plates (Costar group Inc., Boston, MA, USA)에 각 well 당 $500 \mu \mathrm{L}$ 씩 분주하였다. 각 plate well 들을 $4^{\circ} \mathrm{C}$ 에서 24 시간 단클론항체로 미리 코팅하여 고정시 킨 후 well 들을 $1 \% \mathrm{BSA}$ 함유 $\mathrm{PBS}$ 로 3 회 세척하고 이어서 $1 \% \mathrm{BSA} 1 \mathrm{~mL}$ 로 $4^{\circ} \mathrm{C}$ 에서 24시간 block 하였다. 이어서 각 well에 같은 수의 호산구를 분주하고 $10 \%$ heat inactivated fetal bovine serum이 함유된 RPMI 1640에 20 g/ $\mathrm{mL}$ 의 Ber-H8, 대조항체인 동형의 $20 \mu \mathrm{g} / \mathrm{mL}$ 의 IgG1, 10 $\mathrm{ng} / \mathrm{mL}$ 의 IL-5, $10 \mu \mathrm{M} / \mathrm{mL}$ 의 dexamethasone (SigmaAldrich Co.) 을 각각 투여한 후 $37^{\circ} \mathrm{C}, 5 \% \mathrm{CO}_{2}$ 배양기에서 4 시간 또는 24 시간 배양하였다. 또한 호산구를 IL-5 또는 caspase-9 억제제(BD) 와 함께 18시간 및 36시간 동안 별 도 배양한 후 유세포분석기로 자멸사 여부를 측정하였다.

\section{4) 호산구 자멸사}

호산구 생존능은 FITC-conjugated annexin V와 propidium iodide $(\mathrm{PI})$ 을 이용한 apoptosis detection kit (BD)으로 검사하였다.

배양된 호산구를 부드럽게 피펫팅한 후 수거하여 PBS로 1 회 세척하여 $\mathrm{Ca}^{2+}$ 함유 완충액에 현탁하고 실온에서 15 분간 FITC-conjugated annexin V와 반응시키고 $10 \mu \mathrm{g} /$ $\mathrm{mL}$ PI로 염색하여 flow cytometry로 최소 5,000개 이상 의 세포들을 측정하였다.

5) Western blot에 의한 호산구 caspase 발현

호산구를 66시간 배양한 후 수거하여 radioimmunoprecipitation assay buffer를 이용하여 caspase 단백을 추출하였다. $4^{\circ} \mathrm{C}, 13,000 \mathrm{rpm}$ 으로 20 분간 원심분리 후 단 백 농도를 Brad-ford 방법으로 측정하고 5 배 sodium dodecyl sulfate sample buffer로 희석 후 희석된 단백을 $100^{\circ} \mathrm{C}$ 에서 5 분간 비등하였다. $1 \mu \mathrm{g} / \mu \mathrm{L}$ 농도의 단백을 12.5 $\%$ polyacrylamide gel에 투여 후 polyvinylidine difluoride membrane에 옮겨 $100 \mathrm{mV}$ 에서 1시간 동안 분리하 였다. 위의 Membrane을 Tween 20 Tris 완충액과 무지방 분유가 섞인 용액에서 실온에 1 시간 고정하였다. $\mathrm{Mem}-$ brane을 caspase-9 항체(BD) 와 $4^{\circ} \mathrm{C}$ 에서 24 시간 반응시
켜 결합시킨 후 다시 membrane을 실온에서 tris buffered saline/Tween으로 4회 세척하고 이차항체인 Goat antirabbit IgG-HRP conjugate (Bio-Rad Laboratories Inc, Hercules, CA, USA) 와 실온에서 2시간 반응시켰다. 이후 Western blotting luminal reagent kit을 이용하여 procaspase-9 단백을 검출하고 Kodak BioMax Light film에 노 출시켜 현상하였다.

\section{6) 통계 분석}

결과는 mean $\pm \mathrm{SEM}$ 로 표시하였으며 각 군의 차이는 one-way ANOVA로 분석하였으며 P 값이 0.05 미만인 경 우를 통계적으로 유의한 것으로 하였다.

\section{결 과}

\section{1. 호산구의 $\mathrm{CD} 30$ 발현}

호산구의 CD30 발현은 배양시간이 경과함에 따라 지속 적으로 증가하였다. $10 \% \mathrm{FBS} \mathrm{RPMI} \mathrm{배양액} \mathrm{배지에서} \mathrm{0,}$ $4,24,66,90$ 시간 배양 후 $\mathrm{CD} 30$ 양성을 보인 호산구는 flow cytometry에서 $1.2 \%, 3.1 \%, 5.5 \%, 9.4 \%, 17.6 \%$ 로 측정되었다. (각각 $P<0.05, P<0.05, P<0.01, P<0.001$, Fig. 1) $10 \% \mathrm{FBS}$ 에 $10 \mathrm{ng} / \mathrm{mL} \mathrm{IL}-5$ 첨가군과 $1 \% \mathrm{FBS}$ 군 의 24 시간 배양 후 발현율은 각각 $4.8 \%, 6.9 \%$ 로 $10 \% \mathrm{FBS}$

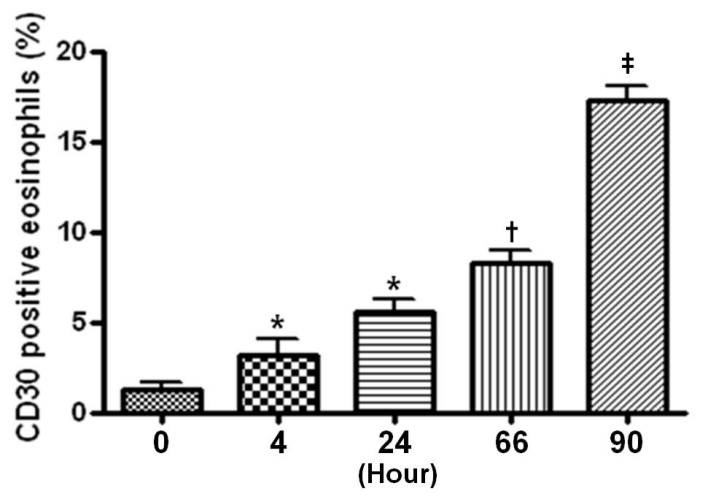

Fig. 1. Expression of CD30 on human blood eosinophils. Isolated eosinophils were incubated in Roswell Park Memorial Institute 1640 media supplemented with $10 \%$ fetal bovine serum and then analyzed CD30 expression in a time dependent manner by flow cytometry using anti-CD30 $\mathrm{mAb}$ and fluorescein isothiocyanate-conjugated $\mathrm{F}\left(\mathrm{ab}^{\prime}\right)_{2}$ goat anti-mouse immunoglobulin $\mathrm{G}\left({ }^{*} P<\right.$ $0.05,{ }^{\dagger} P<0.01,{ }^{\ddagger} P<0.001$ compared with the 0 hour group). 
군과 유의한 차이가 없었다. $(P=0.49$, Fig. 2$)$

\section{2. 항CD30 단클론항체에 의한 호산구 자멸사}

항CD30 단클론항체인 Ber-H8 투여군의 호산구 자멸사 율은 4 시간, 24 시간 배양 시 $29.1 \pm 6.1 \%, 47.3 \pm 4.7 \%$ 를 보여 동형의 대조항체 투여군의 $17.1 \pm 6.7 \%, 29.4 \pm 9.2 \%$ 에 비해 각각 유의한 증가를 보였으며(모두 $P<0.05$, Fig. $3 \mathrm{~A}, \mathrm{~B})$, 대조항체군과 $10 \% \mathrm{FBS}$ 군은 서로 유사한 자멸사 율을 보였다. Ber-H8군의 자멸사율은 4 시간 배양 시

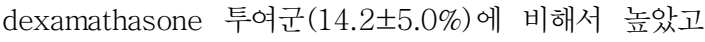
24 시간 배양 $(48.3 \pm 4.3 \%)$ 에서는 유사하였다. 또한 IL-5

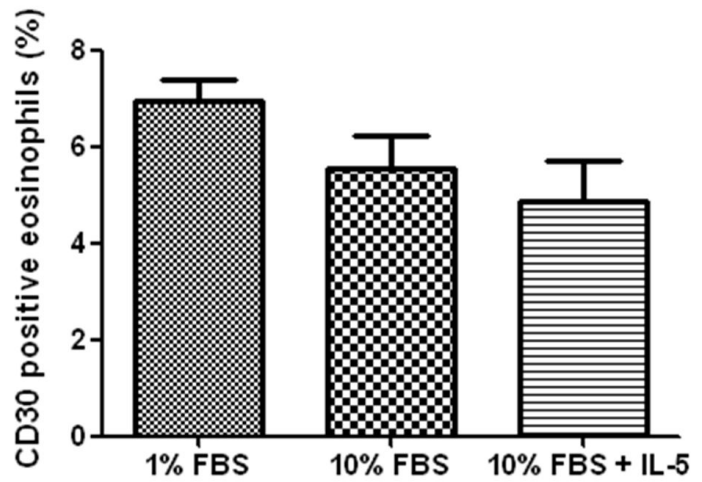

Fig. 2. Expression of CD30 on human blood eosinophils. Isolated eosinophils were incubated for 24 hours in Roswell Park Memorial Institute 1640 media supplemented with either of $1 \%$ fetal bovine serum (FBS), 10\% FBS and 10\% FBS with $10 \mathrm{ng} /$ $\mathrm{mL}$ of interleukin (IL) -5 . The rate was not significantly different each other $(P=0.49)$.
존재하의 4 시간, 24 시간 배양 자멸사율이 $12.5 \pm 4.5 \%$, $16.1 \pm 11.0 \%$ 이었으나 Ber-H8을 첨가하면 $29.4 \pm 6.4 \%$, $47.6 \pm 2.7 \%$ 로 각각 유의하게 증가하여 (모두 $P<0.05$, Fig. $3 \mathrm{~A}, \mathrm{~B}) \mathrm{IL}-5$ 가 CD30 활성화로 인한 자멸사 증가를 억제하 지 못하였다.

CD30 활성화의 호산구 자멸사 유도에 caspase의 관련여 부를 알기 위해 caspase-9 억제제를 투여한 후 자멸사 증가 가 억제되는지를 측정하였다. Caspase-9 억제제 첨가 후의 자멸사율은 18 시간 배양은 $54.8 \pm 6.9 \%$ 에서 $24.5 \pm 6.0 \%$ 로, 36 시간 배양은 $71.5 \pm 11.6 \%$ 에서 $47.8 \pm 11.4 \%$ 로 각각 유 의하게 감소하였으며(모두 $P<0.05$, Fig. $4 \mathrm{~A}, \mathrm{~B}$ ) 대조군 $(23.6 \pm 3.5 \%, 49.1 \pm 9.0 \%)$ 의 자멸사율과 유사하였다.

\section{3. 항CD30 단클론항체에 의한 호산구의 caspase-9 발현}

Ber-H8 배양군의 호산구를 수거 후 Western blotting 을 이용하여 procaspase-9의 발현을 관찰하였다. Ber- H8 군의 36 시간 배양 후 procaspase-9의 발현율이 IL-5 군에 비해 현저히 감소하고 $(P<0.05)$ 대조군에 비해서도 통계적 으로 유의하지는 않으나 낮은 소견을 보였다. (Fig. 5)

\section{고 찰}

본 연구의 목적은 $\mathrm{CD} 30$ 활성화에 따른 호산구 자멸사 여부와 자멸사 발생 기전을 알아보고자 하였다. CD30 발현 율은 시간경과에 따라 지속적으로 증가하였고 IL-5 첨가에 의해서도 영향을 받지 않았으며 호산구 자멸사율은 CD30
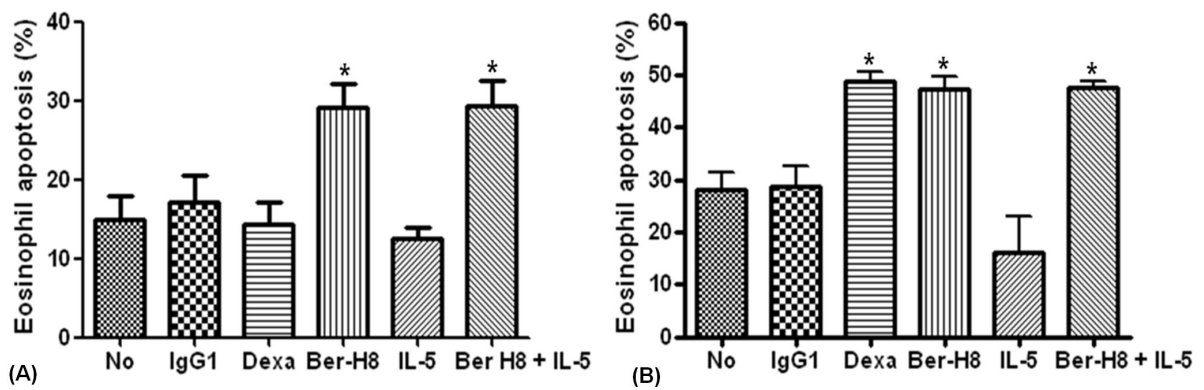

Fig. 3. Effect of immobilized anti-CD30 mAb on eosinophil apoptosis. Eosinophils were cultured in Roswell Park Memorial Institute 1640 media supple mented with $10 \%$ fetal bovine serum of 24 well culture plates previously coated with $20 \mu \mathrm{g} / \mathrm{mL}$ of anti-CD30 $\mathrm{mAb}$ or control immunoglobulin $\mathrm{G}$ (IgG) $1 \mathrm{mAb}$ for 4 hours (A) and 24 hours (B). 10 $\mathrm{ng} / \mathrm{mL}$ of interleukin (IL) -5 , and $10 \mu \mathrm{M} / \mathrm{mL}$ of dexamethasone were added in other plates. Values represent the mean \pm SEM of 4 separate experiments ( $P<0.05$ compared with isotype matched control or media alone). 

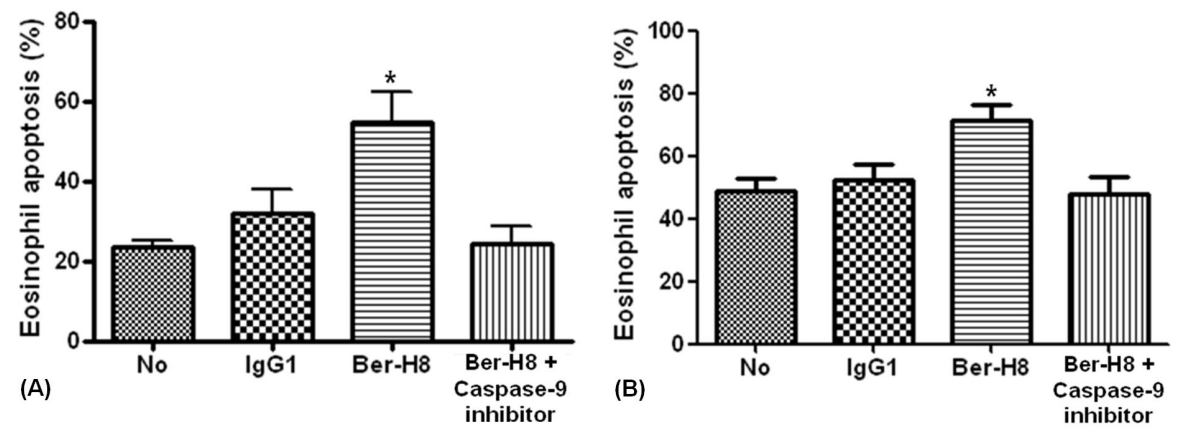

Fig. 4. Effect of caspase-9 inhibitor on immobilized anti-CD30 mAb induced eosinophil apoptosis in Roswell Park Memorial Institute 1640 media supplemented with 10 $\%$ fetal bovine serum. Eosinophils were cultured in 24 well culture plates previously coated with $20 \mu \mathrm{g} / \mathrm{mL}$ of anti-CD30 mAb and $20 \mu \mathrm{g} / \mathrm{mL}$ of control immunoglobulin $\mathrm{G}$ (IgG) $1 \mathrm{mAb}$ for 18 hours (A) and 36 hours (B). Caspase-9 inhibitor was added in other plate. Values represent the mean \pm SEM of 4 separate experiments $\left({ }^{*} P<0.05\right.$ compared with isotype matched control, media alone or with inhibitor).
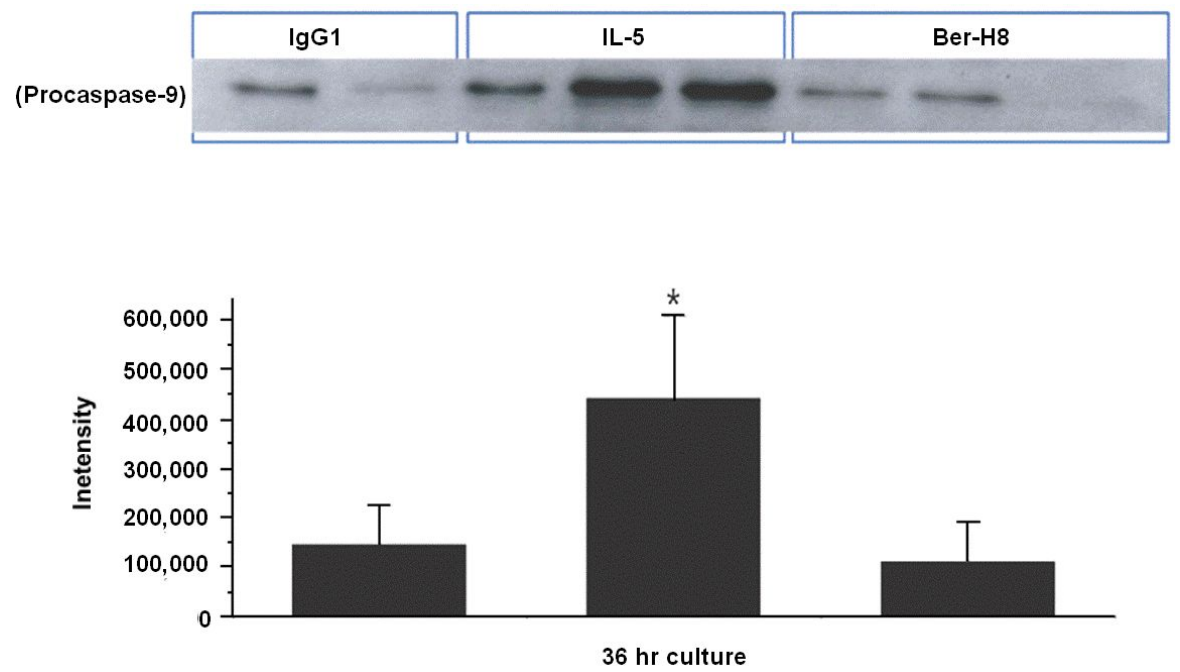

Fig. 5. Expression of procaspase-9 protein in eosinophils. Eosinophils were cultured in Roswell Park Memorial Institute 1640 media supplemented with 10 fetal bovine serum of 24 well culture plates previously coated with $20 \mu \mathrm{g} / \mathrm{mL}$ of anti-CD30 mAb, $20 \mu \mathrm{g} / \mathrm{mL}$ of control immunoglobulin G (IgG) $1 \mathrm{mAb}$ and with addition of $10 \mathrm{ng} / \mathrm{mL}$ of interleukin (IL) -5 for 36 hours. The expression was determined by Western blot $\left({ }^{*} P<0.05\right.$ compared with eosinophils cultured in the presence of IL-5).

발현 정도에 따라 증가하였다. 또한 본 연구에서 처음으로 caspase-9가 CD30 활성화에 의한 호산구 자멸사기전에 연관되어 있음을 규명하였다.

지속적인 호산구 증가증은 만성 알레르기질환 염증조직 에서 관찰되는 특징적 소견으로 호산구 생성이 증가하고 생 존기간도 연장되어 나타난다. 호산구 성장인자인 IL-5, IL-3, GM-CSF는 골수의 호산구 생산증가와 말초혈액의 호
산구 증식을 통해 조직 내 호산구 축적을 일으킨다. 이전에 호산구수와 천식의 연관성에 대해 의문을 가진 보고가 있었 으난 ${ }^{23)}$, 항IL-5제 투여 후 기관지세척액 내 호산구 수가 감 소한 천식환자들의 기관지생검 소견에서 major basic protein 양성 호산구가 다량 관찰되어 조직 내 호산구 활성화에 의해 기도과민성이 지속됨이 알려졌다. ${ }^{24)}$

이처럼 기도염증의 지속은 호산구 활성화가 중요한 역할 
— Hye Jin Lee, et al. : CD30 Activation Induced Eosinophil Apoptosis is Mediated by Caspase-9-

을 하기 때문에 호산구 자멸사에 의해서 효과적으로 억제 될 수 있다. 그러나 호산구 자멸사가 순조롭게 이루어지지 않으면 기도 내 호산구 증가증은 지속되기 때문에 호산구 자멸사를 유도하는 것이 알레르기 질환의 새로운 치료 목표 가 되고 있다. 본 연구에서 호산구 배양기간을 96시간까지 지속한 결과 CD30 발현이 계속 증가하는 추세를 보였으며 (Fig. 1), 배양조건을 달리한 24시간 배양에서는 $1 \% \mathrm{FBS}$ 에서의 CD30 발현이 $10 \% \mathrm{FBS}$ 또는 $10 \% \mathrm{FBS}$ 에 IL-5를 첨가한 경우보다 통계적으로 유의하지는 않으나 높게 나타 났다. 이는 호산구 CD30 발현이 세포 사멸 시까지 계속 증 가하고 호산구 생존이 열악한 조건에서 증가함을 보여준다. 또한 IL-5를 첨가한 전후의 CD30 발현율에 차이가 없는 것 으로 보아 IL-5가 CD30 발현에 영향을 미치지 않음을 알 수 있었다.

본 연구에서 호산구 자멸사율은 모든 군에서 4 시간에서 24 시간으로 배양시간이 경과함에 따라 증가하였는데, 특히 항CD30 단클론항체 투여군에서 가장 높은 자멸사율을 보 이고 스테로이드 투여군보다 높거나 유사하였다. 이는 항 CD30 단클론항체의 배양농도에 따라 호산구 생존율이 감 소하였다는 최근의 보고 ${ }^{25}$ 와 유사한 소견이다. 또한 항 $\mathrm{CD} 30$ 항체 투여군에 IL-5를 첨가한 후에도 자멸사율에 변 화를 보이지 않는 흥미로운 소견을 보였다. 즉, $\mathrm{CD} 30$ 활성 화는 스테로이드에 비해 더 빠르게 호산구 자멸사를 유도하 며 IL-5에 의해서도 자멸사 진행이 억제되지 않는 것으로 보아 혈청결핍 등의 조건에서 보이는 자멸사와는 다른 경로 에 의해 호산구 자멸사를 유도하는 것으로 보인다. 이와 같 은 CD30의 활성화에 의해 유도되는 빠르고 강력한 호산구 자멸사는 호산구 생존이 지속적으로 유지되는 상태를 호전 시킬 수 있는 방안으로 생각되나 실제 임상에서 알레르기염 증 질환의 치료수단으로 이용되기 위해서는 앞으로 많은 연 구를 통한 검증이 필요하다.

$\mathrm{CD} 30$ 은 TNFR 계의 시토카인 수용체로서 세포질 내에 사멸영역 (death domain, $\mathrm{DD}$ ) 을 갖는 일반적인 TNFR계와 달리 세포질에 $\mathrm{DD}$ 는 없지만 TNFR-associated factor (TRAF) 영역을 가지고 있다. 그러므로 CD30 수용체는 배 위자와 결합하면 삼합체(trimerization)를 형성하고 여기 에 TRAF1, TRAF2/5, TRAF3 등이 결집하여 상호작용 함으로서 caspase를 활성화 시킨다. ${ }^{26,27)}$

본 연구에서 나타난 $\mathrm{CD} 30$ 단클론항체 투여 시의 호산구 자멸사 증가도 $\mathrm{CD} 30$ 와 결합한 후 $\mathrm{TRAF}$ 들과 연계하여 caspase-9이 활성화되기 때문에 유발되는 것으로 생각된 다. 세포 자멸사는 사멸수용체 (death receptor)를 통해 이
루어지는지 여부에 따라 자멸사에 이르는 신호전달경로가 다르다. 즉, caspase-8과 같이 사멸수용체에 의존하여 활성 화되는 경로와 ${ }^{28,29)}$ 사멸수용체에 의존하지 않고 미토콘드 리아에 의해 조절되는 caspase 활성 경로가 있는데 후자는 procaspase-9이 자멸사 초기에 미토콘드리아에서 유리된 cytochrome c에 의해 활성화된 Apaf1와 결합하면 caspa$\mathrm{se}^{-9}$ 으로 활성화된다. ${ }^{30)}$

본 연구에서 caspase-9 억제제가 항CD30 단클론항체 에 의한 호산구 자멸사를 현저히 감소시키고(Fig. 4A, B) procaspase-9의 발현은 항CD30 단클론항체와 배양한 호 산구에서 낮았으나 IL-5 존재 하에서는 증가하였다. 이는 앞의 결과에서 보인 바와 같이 IL-5가 호산구 CD30 발현에 영향을 미치지 않아 procaspase-9의 발현율이 높게 나타난 것으로 생각되며 한편 항 $\mathrm{CD} 30$ 단클론항체 투여 후에는 $\mathrm{CD} 30$ 의 교차결합에 의해 procaspase-9이 활성상태의 caspase-9으로 전환되어 호산구 자멸사를 항진시킨 것으 로 보인다. 더구나 최근의 연구에서 caspase-3, -8 억제제 투여 후에도 항CD30 단클론항체에 의한 호산구 자멸사에 영향을 미치지 않았다고 ${ }^{31)}$ 하였는데 본 연구에서도 항 $\mathrm{CD} 30$ 단클론항체와 배양한 호산구에서 caspase-8이 Western blot에서 발현되지 않아 서로 유사한 소견을 보였 다. 즉, $\mathrm{CD} 30$ 에 의한 호산구 자멸사는 사멸수용체에 의존 하지 않고 미토콘드리아에 의해 직접 조절되는 별도의 자멸 사 신호전달경로에 따라 caspase-9이 활성화되어 일어나 는 것으로 추정된다. 그러나 호산구 자멸사 기전을 명확히 밝히기 위해서는 향후 TRAF 단백질과 같은 광범위한 신호 전달분자에 대한 연구가 필요하다.

본 연구는 알레르기질환이 없는 건강한 공여자의 호산구 만을 이용하였기 때문에 제한적 결과가 나올 수 있는 제한 점이 있으며 정상인과 알레르기 질환자의 호산구 자멸사에 차이가 있는지 아직 명확히 알려져 있지 않으나 알레르기 환자의 호산구를 이용한 자멸사 연구도 추가적으로 필요하 다고 생각된다.

이상의 연구에서 결론적으로 $\mathrm{CD} 30$ 활성화로 유발되는 호산구 자멸사에 caspase-9가 매개작용을 할 것으로 추정 되었다.

\section{요 약}

목 적: $\mathrm{CD} 30$ 은 자멸사가 진행중인 호산구에서 발현이 더 증가되는 것으로 알려져 있으나 실제 CD30 활성화가 어 떻게 호산구 자멸사를 일으키는지는 명확하지 않다. 본 연구 
에서는 인체세포 자멸사의 중요한 요소인 caspase가 CD30 활성화에 의한 호산구 자멸사에 미치는 역할을 규명하고자 한다.

방 법: 건강한 성인의 말초혈액 $90 \mathrm{~mL}$ 를 채취하여 혈액 을 Percoll 밀도차와 MACS magnetic system으로 호산구 를 분리한 후 호산구 표면 CD30 발현율과 자멸사율을 flow cytometry 로 측정하였다. 호산구 배양은 CD30 단클론항 체와 동형의 immunoglobulin G1을 대조항체로 하여 24 well plates에 미리 코팅하고 고정한 후 호산구를 분주하고 interleukin (IL) -5 , Dexamethasone을 첨가하여 4시간, 24시간 배양한 후 자멸사 정도를 각각 비교하였다. 또한 $\mathrm{CD} 30$ 에 의한 호산구 자멸사에서 caspase의 역할을 규명하 기 위해 caspase-9 억제제를 첨가한 후 배양하여 자멸사율 변화를 측정하고 Western blotting을 이용하여 procaspase-9 단백을 검출하였다.

결 과 : 호산구 표면 CD30 발현은 배양시간이 연장됨에 따라 점점 증가하였다. 호산구 자멸사율은 항CD30 단클론 항체에서 4 시간, 24 시간 배양 시 $29.1 \pm 6.1 \%$ 와 $47.3 \pm 4.7$ $\%$ 으로 대조항체의 $17.1 \pm 6.7 \%$ 와 $29.4 \pm 9.2 \%$ 에 비해 유의 하게 증가하였다 $(P<0.05)$. 항 $\mathrm{CD} 30$ 항체투여군의 자멸사 율은 스테로이드 투여군에 비해 빠르게 중가하였으며 IL-5 투여군의 호산구 생존능을 현저히 감소시켰다. 또한 항 CD30 항체투여군에 caspase-9 억제제를 첨가하면 18시간 과 36 시간 배양 후 자멸사율이 첨가전의 $54.8 \pm 16.9 \%$ 와 $71.5 \pm 11.6 \%$ 에서 $24.5 \pm 6.0 \%$ 와 $47.8 \pm 11.4 \%$ 로 각각 유 의하게 감소하였으며 $(P<0.05)$ 항CD30 항체투여군의 procaspase-9 단백의 발현이 IL-5 투여군과 대조항체군에 비해 저하됨을 Western blot을 통해 관찰하였다.

결 론 : 본 연구에서 $\mathrm{CD} 30$ 활성화는 호산구 자멸사를 촉 진하며 caspase-9 활성화가 자멸사 과정에서 중요한 역할 을 할 것으로 보인다.

\section{참 고 문 헌}

1. Gleich GJ. The eosinophil and bronchial asthma: current understanding. J Allergy Clin Immunol 1990;85:422-36.

2. Gleich GJ. Mechanisms of eosinophil-associated inflammation. J Allergy Clin Immunol 2000; 105:651-63.

3. Sanderson CJ. Interleukin-5: an eosinophil growth and activation factor. Dev Biol Stand 1988;69:23-9.
4. Kerr JF, Wyllie AH, Currie AR. Apoptosis: a basic biological phenomenon with wide-ranging implications in tissue kinetics. $\mathrm{Br} \mathrm{J}$ Cancer 1972;26:239-57.

5. Allen RT, Hunter WJ 3rd, Agrawal DK. Morphological and biochemical characterization and analysis of apoptosis. J Pharmacol Toxicol Methods 1997;37:215-28.

6. Alnemri ES, Livingston DJ, Nicholson DW, Salvesen G, Thornberry NA, Wong WW, et al. Human ICE/CED-3 protease nomenclature. Cell 1996;87:171.

7. Matsumoto K, Schleimer RP, Saito H, Iikura Y, Bochner BS. Induction of apoptosis in human eosinophils by anti-Fas antibody treatment in vitro. Blood 1995;86:1437-43.

8. Walsh GM, Williamson ML, Symon FA, Willars GB, Wardlaw AJ. Ligation of CD69 induces apoptosis and cell death in human eosinophils cultured with granulocyte-macrophage colony-stimulating factor. Blood 1996;87:2815-21.

9. Blaylock MG, Sexton DW, Walsh GM. Ligation of CD45 and the isoforms CD45RA and CD45RB accelerates the rate of constitutive apoptosis in human eosinophils. J Allergy Clin Immunol 1999;104:1244-50.

10. Dürkop H, Latza U, Hummel M, Eitelbach F, Seed B, Stein H. Molecular cloning and expression of a new member of the nerve growth factor receptor family that is characteristic for Hodgkin's disease. Cell 1992;68:421-7.

11. Stein H, Mason DY, Gerdes J, O'Connor N, Wainscoat J, Pallesen G, et al. The expression of the Hodgkin's disease associated antigen $\mathrm{Ki}^{-}$ 1 in reactive and neoplastic lymphoid tissue: evidence that Reed-Sternberg cells and histiocytic malignancies are derived from activated lymphoid cells. Blood 1985;66:848-58.

12. Jung W, Krueger S, Renner C, Gause A, Sahin $\mathrm{U}$, Trümper L, et al. Opposite effects of the CD30 ligand are not due to CD30 mutations: results from cDNA cloning and sequence comparison of the CD30 antigen from different sources. Mol Immunol 1994;31:1329-34.

13. Masuda M, Ishida C, Arai Y, Okamura T, Ohsawa M, Shimakage M, et al. Dual action of CD30 antigen: anti-CD30 antibody induced apoptosis and interleukin-8 secretion in $\mathrm{Ki}-1$ lymphoma cells. Int J Hematol 1998;67:257-65. 
14. Mir SS, Richter BW, Duckett CS. Differential effects of CD30 activation in anaplastic large cell lymphoma and Hodgkin disease cells. Blood 2000;96:4307-12.

15. Gruss HJ, Boiani N, Williams DE, Armitage RJ, Smith CA, Goodwin RG. Pleiotropic effects of the CD30 ligand on CD30-expressing cells and lymphoma cell lines. Blood 1994;83:2045-56.

16. Muta H, Boise LH, Fang L, Podack ER. CD30 signals integrate expression of cytotoxic effector molecules, lymphocyte trafficking signals, and signals for proliferation and apoptosis. J Immunol 2000;165:5105-11.

17. Pinto A, Aldinucci D, Gloghini A, Zagonel V, Degan M, Improta S, et al. Human eosinophils express functional CD30 ligand and stimulate proliferation of a Hodgkin's disease cell line. Blood 1996;88:3299-305.

18. Chiarle R, Podda A, Prolla G, Gong J, Thorbecke GJ, Inghirami G. CD30 in normal and neoplastic cells. Clin Immunol 1999;90:15764.

19. Berro AI, Perry GA, Agrawal DK. Increased expression and activation of CD30 induce apoptosis in human blood eosinophils. J Immunol 2004;173:2174-83.

20. Matsumoto K, Terakawa M, Miura K, Fukuda S, Nakajima T, Saito H. Extremely rapid and intense induction of apoptosis in human eosinophils by anti-CD30 antibody treatment in vitro. J Immunol 2004;172:2186-93.

21. Hansel TT, De Vries IJ, Iff T, Rihs S, Wandzilak M, Betz S, et al. An improved immunomagnetic procedure for the isolation of highly purified human blood eosinophils. J Immunol Methods 1991;145:105-10.

22. Simon HU, Yousefi S, Schranz C, Schapowal A, Bachert C, Blaser K. Direct demonstration of delayed eosinophil apoptosis as a mechanism causing tissue eosinophilia. J Immunol 1997; 158:3902-8.

23. Leckie MJ, ten Brinke A, Khan J, Diamant Z, O'Connor BJ, Walls CM, et al. Effects of an interleukin-5 blocking monoclonal antibody on eosinophils, airway hyper-responsiveness, and the late asthmatic response. Lancet 2000; 356: 2144-8.

24. Flood-Page PT, Menzies-Gow AN, Kay AB, Robinson DS. Eosinophil's role remains uncertain as anti-interleukin -5 only partially depletes numbers in asthmatic airway. Am J Respir Crit Care Med 2003;167:199-204.

25. Matsumoto K, Terakawa M, Fukuda S, Saito H. Rapid and strong induction of apoptosis in human eosinophils by anti-CD30 mAb-coated microspheres and phagocytosis by macrophages. Int Arch Allergy Immunol 2007;143 Suppl $1: 60-7$.

26. Gedrich RW, Gilfillan MC, Duckett CS, Van Dongen JL, Thompson CB. CD30 contains two binding sites with different specificities for members of the tumor necrosis factor receptor-associated factor family of signal transducing proteins. J Biol Chem 1996;271: 12852-8.

27. Horie R, Aizawa S, Nagai M, Ito K, Higashihara $\mathrm{M}$, Ishida $\mathrm{T}$, et al. A novel domain in the CD30 cytoplasmic tail mediates NFkappaB activation. Int Immunol 1998;10:203-10.

28. Dempsey PW, Doyle SE, He JQ, Cheng G. The signaling adaptors and pathways activated by TNF superfamily. Cytokine Growth Factor Rev 2003;14:193-209.

29. Muzio M, Stockwell BR, Stennicke HR, Salvesen GS, Dixit VM. An induced proximity model for caspase-8 activation. J Biol Chem 1998; 273:2926-30.

30. Zou H, Henzel WJ, Liu X, Lutschg A, Wang X. Apaf-1, a human protein homologous to C. elegans CED-4, participates in cytochrome $\mathrm{c}^{-}$ dependent activation of caspase-3. Cell 1997; 90:405-13.

31. Matsumoto K, Terakawa M, Fukuda S, Saito H. Analysis of signal transduction pathways involved in anti-CD30 mAb-induced human eosinophil apoptosis. Int Arch Allergy Immunol 2010;152 Suppl 1:2-8. 